\title{
食品廃棄低減化のための食品品質表示
}

\author{
佐藤みずほ・中野 冠 \\ (慶應義塾大学大学院システムデザイン・マネジメント研究科)
}

\section{The display on food product influencing the reduction of the amount of food waste}

\author{
Mizuho Sato, Masaru Nakano \\ Graduate School of System Design and Management, Keio University, \\ 4-1-1, Hiyoshi, Kohoku-ku, Yokohama-shi, Kanagawa, 223-8526 \\ 干 223-8526 横浜市港北区日吉 4-1-1
}

\begin{abstract}
Date displays on food products, from the progress in processing techniques and international standards, have together caused a change in the "production data" to time limit indicators such as "use-by date" or "best-before date". This paper focuses on the number of food poisoning outbreaks and food imports, particularly the import of milk and other dairy products, and analyzed the change in food waste after changes in the display on food products. Consumers were given questionnaires about the effects on them of the "use-by date" or "best before date" especially effecting the on decreasing food waste by the consumers. The main points of the study are as follows:

(1) The number of food poisoning outbreaks increased after the change in the display on the food products. Moreover, the total amount of food waste from consumers calculated as waste energy increased after the change in the display on the food products.
\end{abstract}

(2) A number of consumers prefer food products with "production data".

(3) A number of consumers want to calculate the eatable period of food products. If information, which enables consumers to calculate the eatable periods is provided, it may reduce the amount of food waste.

(4) Information such as the inspection contents, safety factors, a one-third rule in addition to the "production date" helps consumers reduce food waste. If such information is provided, we estimated that the amount of food waste will decrease by about 1-2.72million tons.

\section{1. 緒言}

わが国の食品廃棄量は年間約 2,200 万トンとわれて おり, その半数, 約 1,100 万トンは消費者から廃棄され る量である ${ }^{1)}$ 。その主な原因は, 野菜などの調理屑, 過 剩廃棄, 食べ残し, 鮮度の低下による腐敗, カビの発生 に加えて, 消費期限・賞味期限切れに原因がある場合が 多い2)。

このような期限切れによる食品廃棄の低減化を目指し て, 調理方法の工夫, 家庭で作る量の調節, 残さず食べ
る, 冷凍保存する, 購入時に必要量を確認する, 品質や 期限表示をこまめに確認し，使い切るなどの方法が提案 されている ${ }^{2)}$ 。

消費期限は，安全に食べられる期間を指しており，品 質の劣化の早い食品に表示されている ${ }^{3,4)}$ 。賞味期限は, 美味しく食べられる期間を示しておりこの期間を過ぎて もすぐに食べられないということではない。しかし, こ の違いは消費者に正確に認識されるには至っておらず, 消費者からはわかりづらいとの意見も多数届けられてお $り^{5)}$, 消費者の理解不足が食品廃棄量に影響している可 
能性がある。

食品表示に関して欧米では，主に栄養表示，健康表示， 品質表示について検討がなされている。栄養表示と消費 者行動に関しては, イギリスでの信号機表示システム ${ }^{6)}$ についての研究がある。信号機表示システムとは, 任意 表示ではあるが，肥満予防を目的として，栄養量（脂肪 / 飽和脂肪酸，砂糖，塩分）の含有量を「多い HIGH」 $=$ 赤,$\lceil$ 中間 $\mathrm{MED}\rfloor=$ 黄,$\lceil$ 少ない $\mathrm{LOW} 」=$ 青で商品に 表示するシステムのことである。この研究では, 裏面の 義務表示より正面の簡略表示が見やすく，栄養表示を正 確に理解するためには信号機表示システムにさらに栄養 評価の総合スコアを加えることにより消費者の理解度が 高くなるといった報告がなされている ${ }^{6)}$ 。また, 健康表 示に関しては，科学的根拠のレベルが高くなれば，消費 者の製品に対する信頼度は高まり，健康表示の影響力も 高まると報告されている7 が, いずれも肥満防止や健康 増進を目的とした研究であり, 廃棄量低減化にはつなが るものではない。

アメリカにおける品質表示に関する研究では, 消費者 は表示より自らの判断で品質期限を決めているとの報告 があり，消費期限や賞味期限といった品質表示よりは自 らの五感を大切にして判断している ${ }^{8)}$ と記載されており, 品質表示と消費者行動の関係は示されているが, 品質表 示と食品廃棄との関係については解析が進んでいない。 国内でも栄養表示, 健康表示, 品質表示の研究はされて いるが, 食品廃棄量低減化の提案にはつながっていな $\omega^{9,10)}$ 。

わが国の食品の品質表示は, 1997年以降, それまで「製 造年月日」（または加工年月日）で表示されていた日付 表示が，「消費期限」，「賞味期限」などの「期限表示」 に変更された。この変更理由は, 食品の保存技術の進歩 により製造日表示から消費者の経験にもとづく保存が可 能な期間の判断が適切ではなくなったこと，また，国際 規格との調和が理由とされた。しかし，一部の消費者団 体からは食品廃棄量を増加させるのではないかという危 惧もあった ${ }^{11}$ 。

そこで, 本研究では, 食品の品質表示が製造日表示か ら期限表示になったことによる食品廃棄への影響につい て, 過去のデータをもとに解析し, 品質表示に関する消 費者の理解と定着の程度を調査し，消費者意識にもとづ く食品廃棄量の低減化を可能とする食品の品質表示のあ り方を提案することを目的とした。

具体的には, 過去のデータから（1）では, 品質表示 変更前後における食品廃棄への影響を, 品質表示変更理 由の影響については, 品質表示変更理由の影響について 1）～3）の内容で解析した。具体的には，1）では， 食中毒発生件数を用いて解析した。2）では, 食品輸入 量および牛乳・乳製品の輸入量に焦点をあてて解析した。 3 ) では, 食品の品質表示の変更前後での食品廃棄量 (食 品廃棄エネルギー）への影響を解析した。（2）では,
品質表示に関する消費者アンケート調査を実施し, 食品 の品質表示に関する消費者の理解と定着の程度を解析し た。（3）では，消費者意識にもとづく食品品質表示の 提案を示した。（4）では，品質表示の改善による消費・ 賞味期限切れの食品廃棄量低減化の推定と低減化を実現 するための広報についてアンケート結果をもとに示した。

\section{2. 方 法}

\section{（1）品質表示変更前後における食品廃棄への影響分析}

食品の品質表示が「製造年月日」(または加工年月日) 表示から，「消費期限」，「賞味期限」への「期限表示」 へ変更されたことにより，製造業者に日持ちの判断を委 ね，消費者には結果のみを一方的に知らせるものになり， 食品の重要な情報については, その決定プロセスを含め て業者任せにしてしまうことに対して一部の消費者団体 より危惧が示されていた ${ }^{111}$ 。これらを踏まえて表示変更 の理由（食品の保存技術の進歩と国際規格との調和）が その後, どのように影響したか厚生労働省および農林水 産省の報告 ${ }^{12-14)}$ を用いて解析した。解析には, 一元配置 分散分析を行い，分散分析で主効果がみられた場合には, Tuykey 法による多重比較を行った。統計処理には, Microsoft Office Excel 2007の分析ツールおよび IBM SPSS Statistics 19を用いた。

\section{1 ) 食中毒発生件数の推移}

食品の保存技術の進歩により消費者の経験にもとづく 保存可能な期間の判断が適切ではなくなったことが, 品 質表示変更理由の一つであったが，もし，品質表示変更 理由が消費者の行動に適切に影響したと考えると，一つ の指標として食中毒の発生件数は品質表示変更後に減少 すると予想される。そこで, 品質表示変更後, 食中毒発 生件数がどのように推移したかについて，厚生労働省の 報告 ${ }^{12)}$ を用いて解析した。食中毒発生件数については, 原因施設別, 物質別, 商品別に分け, 変更前 (1990 1994年) と変更後の1998～2002年 (1)，2003～2007年 (2) のそれぞれの 5 年間で集計し解析した。

\section{2 ) 食品輸入量および牛乳・乳製品の輸入量の変化}

国際規格の調和についても品質表示変更理由の一つに あげられていた。そこで，品質表示変更前後における， 食品輸入量の推移を食料需給表 ${ }^{13)}$ をもとに全体の輸入量 と比較的相関の高い牛乳・乳製品を取り上げて解析した。 食品輸入量は，変更前（1990～1994年）と変更後1998～ 2002年（1)，2003～2007年（2）の 5 年間で集計した。

\section{3 ) 食品廃棄量（食品廃棄エネルギー）の変化}

食品廃棄物量を食料需給表 ${ }^{13)}$ から得られる供給エネル ギーと国民健康栄養調査 ${ }^{14}$ から得られる摂取エネルギー の差を廃棄エネルギー值として算出し, 品質表示の変更 前後における推移を検討した。廃棄エネルギーは, 品質 表示変更前（1990～1994年）と変更後1998～2002年 (1)), 2003～2007年（2）の 5 年間で集計した。なお，廃棄工 ネルギー $(Y i)$ を下記に示す式により算出した。 


$$
\begin{aligned}
& Y i=X i-Q i \\
& X i \text { : 供給エネルギー } \quad(\mathrm{kcal}) \\
& Q i \text { : 摂取エネルギー }(\mathrm{kcal}) \\
& \quad i=1990 \sim 2008 \text { 年 }
\end{aligned}
$$

（2）品質表示に関する消費者アンケート調査方法

\section{1) 調査対象}

調査対象は，日本在住の20歳代以上の男女合わせて 150名とし，アンケート調査を行った。消費者全体の意 識を知るためにアンケート対象者の性別, 年歯令, 職業お よび家族構成は日本の人口統計情報 ${ }^{15,16)}$ を参考にしてわ が国の人口構成を考慮したものとした。

\section{2 ) 調查時期と方法}

調査時期は，2011年 7 月から10月にかけて実施した。 調査方法は，質問用紙はメールもしくは郵送にて配布収 集した。

\section{3 ) 調査項目}

アンケートは，まず第 1 に「消費期限」と「賞味期限」 の違いを正確に理解しているか, またその認識の違いが 廃棄行動に影響しているかを明らかにするために実施し た。第 2 に消費期限」と「賞味期限」の設定について, その設定の背景をどの程度認知しているか，また，食の 保存期間をどの程度，推定を可能としており，期限表示 の情報は廃亲行動に影響を与えるかどうかを調べた。第 3 に任意表示（特に製造日表示）について調べた。この 内容は, 食品廃棄低減化のためには, 消費者が食の保存 期間を自ら計算することは重要であり，その一つの情報 として，製造日表示があるため，消費者意識を調べた。 第 4 に消費者の食品廃棄行動の現状について調べた。

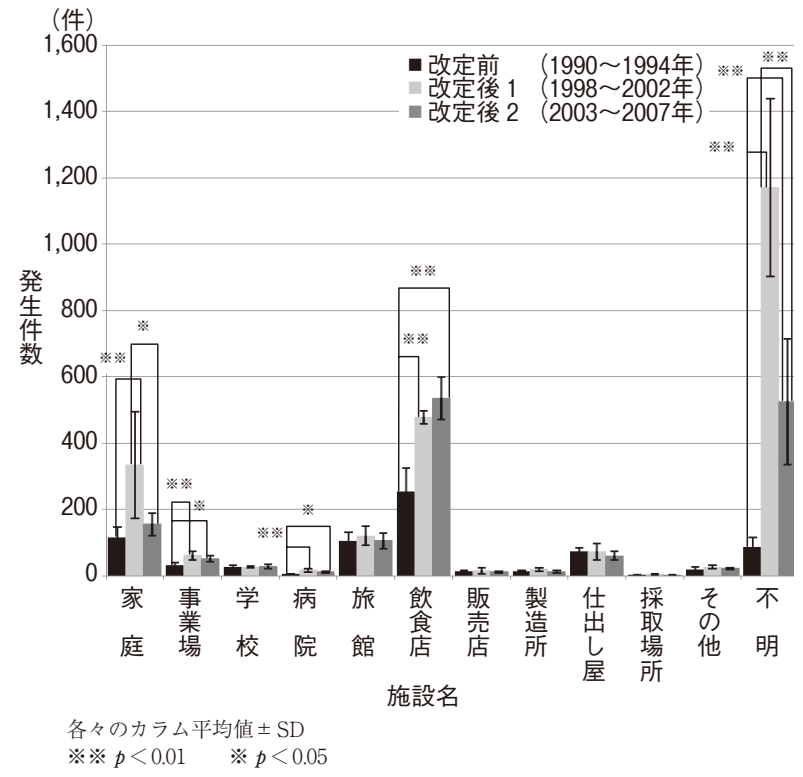

図 1 施設別 食中毒発生件数

\section{3. 結果および考察}

\section{（1）品質表示変更前後における食品廃棄への影響分析}

1) 食中毒発生件数の推移

食中毒発生件数の原因施設別の結果では，家庭，事業 場, 学校, 病院, 旅館, 飲食店, 販売店, 製造所, 採取 所（きのこ等），仕出し屋，その他，不明における品質 表示変更前と変更後(1)およ゙(2)の 5 年間の食中毒発生件 数を比較すると, 家庭, 事業場, 病院, 飲食店, 不明で は, 品質表示変更後, 有意に食中毒発生件数は増加して いた。

一方で学校, 旅館, 販売所, 製造所, 仕出し屋, 採取 所，その他での食中毒発生件数については差がみられな

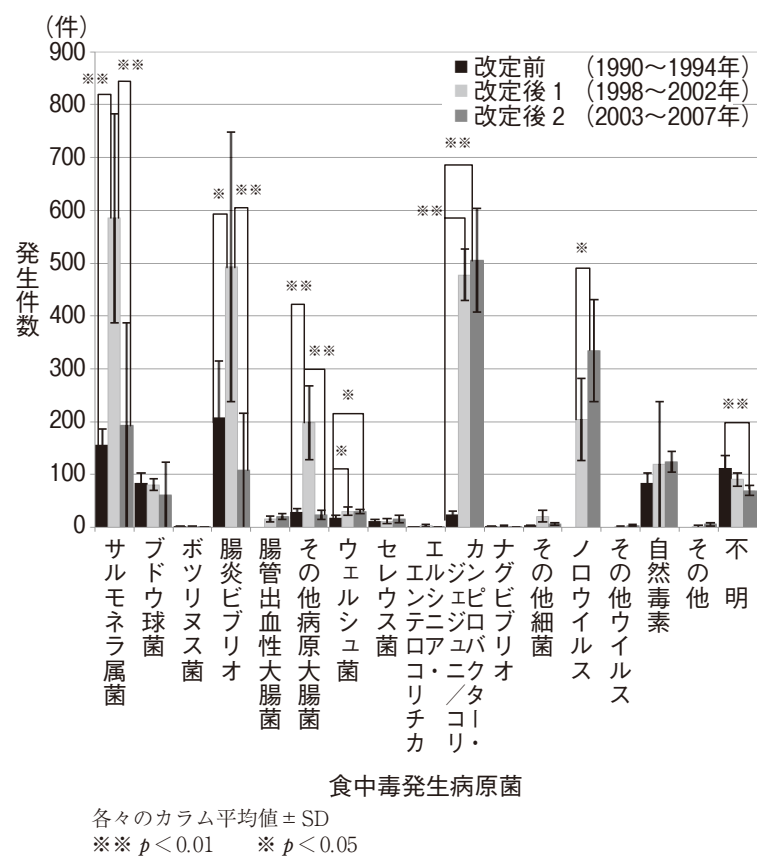

図 2 病原菌別食中毒発生件数

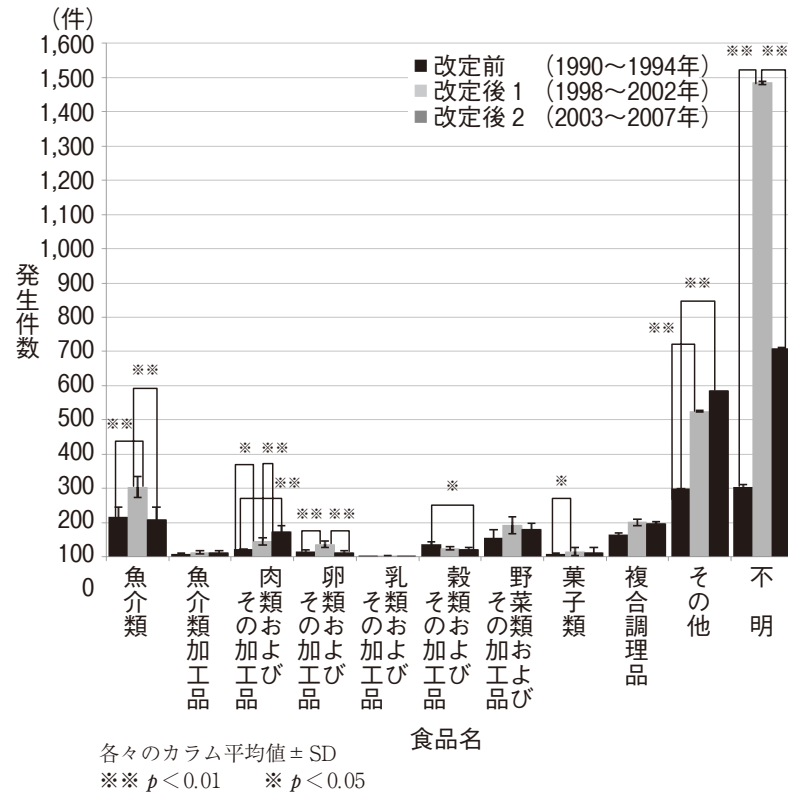

図 3 食品別食中毒発生件数

$168(40)$ 
かった（図 1 ）。

食中毒を発生させる物質（病原菌やウイルス）の一時 的流行が品質表示変更後, 食中毒発生件数を増加させる 可能性も考えられるため, 物質別の発生件数の有意差を 調べた。その結果, サルモネラ属菌, 腸炎ビブリオ, そ の他病原大腸菌, ウェルシュ菌, カンピロバクター・ジェ ジュニ/コリ，による食中毒では品質表示変更前より変 更後で有意に増加しており，発生件数の上昇は，特定の 病原菌の一時的な流行ではなく, 多様な病原菌が原因と なっていたと考えられた。なお，腸管性出血性大腸菌群 ノロウイルスなど品質表示改定後に発生したものもある が, これらの発生と品質表示変更との関連については不 明であった（図 2 )。

また，食品別と食中毒発生件数の関係を解析すると， 魚介類, 肉類およびその加工品, 卵類およびその加工品, 菓子類では品質表示変更後，有意に発生件数が増加した。 穀類およびその加工品では, 品質表示変更後有意に減少 していた（図 3 )。

上記のことから，食中毒発生件数において特定の場所 原因物質および食品との相関はみられなかったことから さまざまな原因が食中毒発生件数の増加につながったと 考えられた。このようなことから考えると，消費期限， 賞味期限の意味が消費者に正確に理解されていなかった ことが食中毒発生件数上昇の原因の一つとなったのでは ないかと推察された。

2 ) 食品輸入量および牛乳・乳製品の輸入量の変化

食品輸入量および牛乳・乳製品の年次輸入量は品質表 示変更後, (1), (2)において有意 $(p<0.01)$ に増加して おり，品質表示変更の一つの原因であった国外からの食 品輸入量の増加に関する目標は達成されたと示唆された (図 4 )。

3 ）食品廃棄量（食品廃棄エネルギー）の変化 品質表示変更前（1990～1994年）と変更後1998～2002
年（1)）と2003〜2007年（2)）のそれぞれ 5 年間の平均

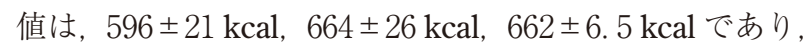
品質表示変更前と変更後 (1), (2) に有意差 $(p<0.01)$ が あり，品質表示変更の改定時に消費者団体が懸念してい た食品廃棄の増加が指摘通りになったと示された(図 5 )。

\section{（2）品質表示に関する消費者アンケート調査結果}

鹿児島県での調査では，食品について不安に思う人が 86.7\%にのぼっており，特に女性・主婦・同居人数が多 い人が食の安心・安全について不安を感じるとともに,

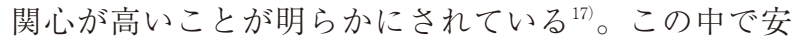
心・安全につながる表示としては，「賞味期限」，「消費 期限」，「製造年月日」を参考にするとの回答が多いこと がわかった。また，消費者による食品口スの発生要因と 削減のための取り組みの現状についての報告 ${ }^{18)}$ では, 期 限表示についての理解不足が食品ロスにつながっている と指摘されている。

このような情報を踏まえて実施したアンケート調査の 結果は次のとおりであった（表 1 )。

1 ）「消費期限」と「賞味期限」の違いの消費者意識 アンケートの結果は, 消費期限, 賞味期限の理解はし ていると回答した消費者が半数以上いたが，正確に理解 してない消費者も $38.0 \%$ お，その中には期限が切れる と直ちに廃棄している消費者が $7 \%$ いたことから, 消費 者に品質表示の意味を正確に伝達することが重要である と示唆された。

2 ）「消費期限」と「賞味期限」の設定の消費者意識 消費期限 ・賞味期限の設定の背景（品質期限設定の検 査内容, 1 / 3 ルール, 安全係数) をほとんど知らない 消費者が多かった。しかし，家庭での保存が可能な期間 の推定については，81.3\%の消費者が「ある程度可能で ある」，「可能である」，「できる」と回答していた。しか し，何を根拠として「ある程度可能である」，「可能であ

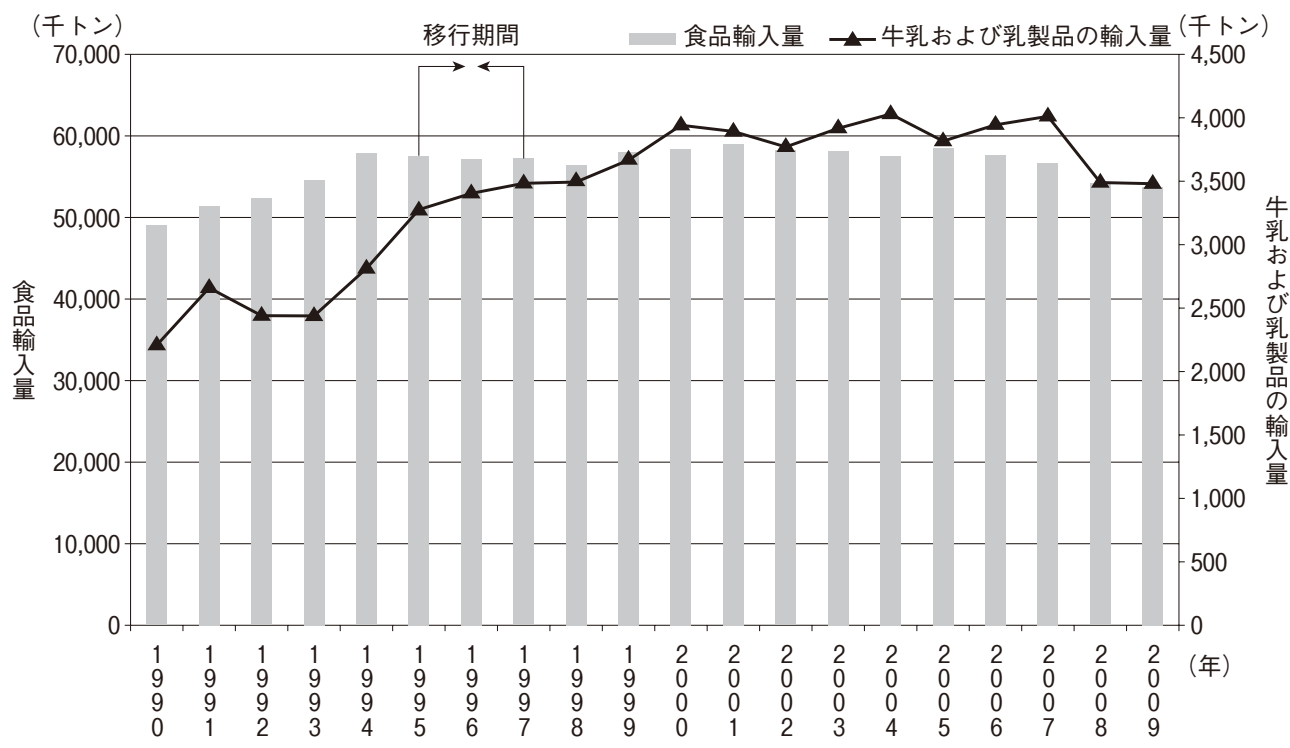

図 4 輸入量および牛乳・乳製品の輸入量 


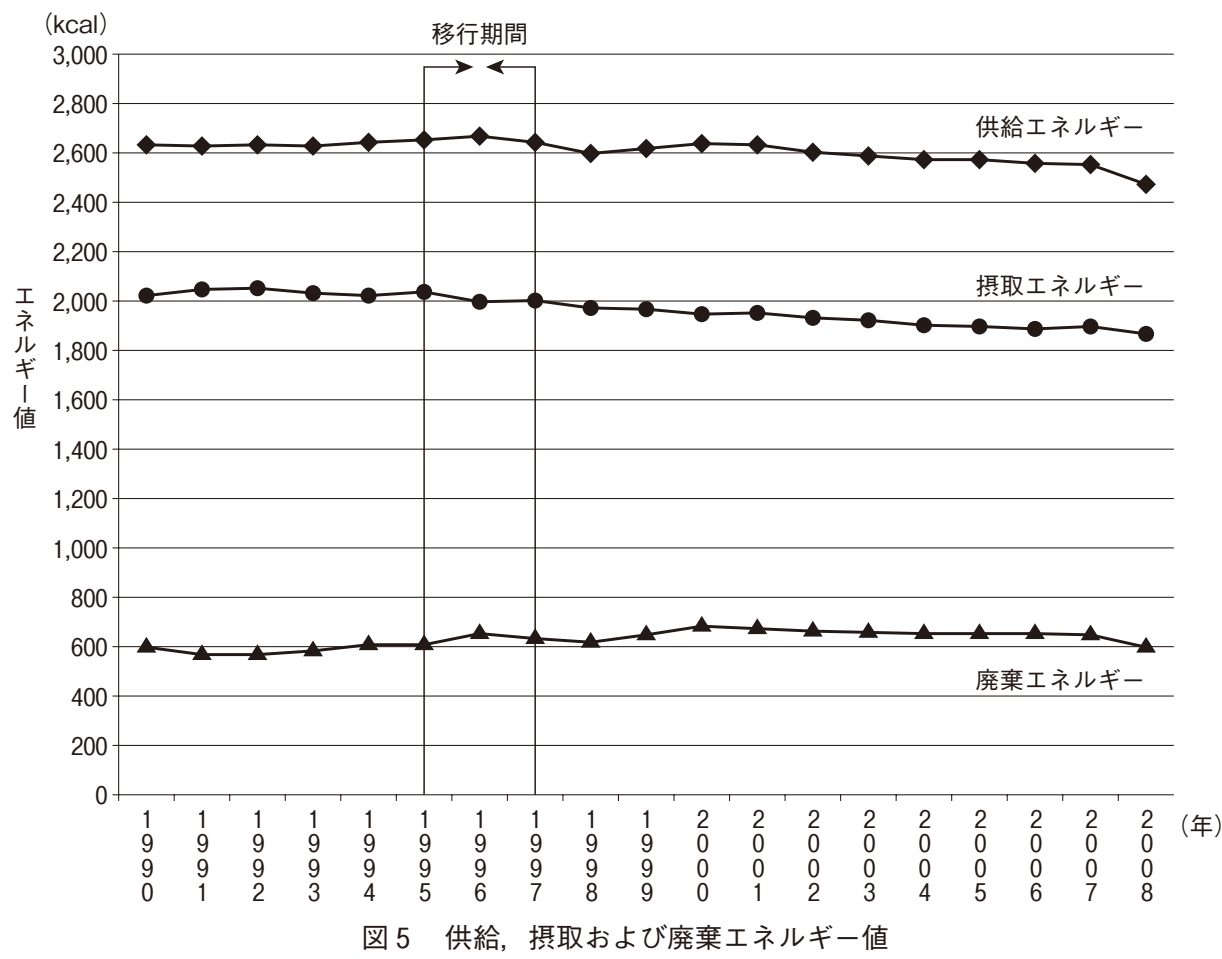

る」，「できる」と判断しているかが不明であり，誤解に もとづく判断であれば食中毒発生に結びつく危険性があ ると推察された。

一方，家庭での保存が可能な期間の推定を可能とした 消費者の中では，消費期限が過ざると直ちに廃棄する人 は25名 $(16.7 \%)$ ，賞味期限が過ぎると直ちに廃棄する 人が 13 名 $(8.7 \%)$ いたことから，期限表示の記載が消 費者の廃棄行動に影響すると推察された。

したがって，消費期限・賞味期限の設定の背景を表示 することにより期限切れですぐに廃棄する人の割合が低 減されるのではないかと推察された。

\section{3 ) 任意表示としての製造日表示の消費者意識}

製造日表示の記載は消費者にとって家庭での食が可能 な期間を推定する上で，重要な情報であり，アンケート の結果においても製造日の表示を望む消費者が多かった。 したがって，製造日表示を記載することは食品廃棄低減 化においても重要な情報であると示唆された。「製造年 月日」表示を任意表示として復活させることは，食の保 存期間の算出を可能とする情報の強化につながり，食品 廃棄行動が改善されるのではないかと推察された。

\section{4 ）食品廃棄行動と食品表示の消費者意識}

食品廃棄を考える上で，品質表示は重要である。2000 年の埼玉県の919名を対象とした調査においても $25.4 \%$ の人が賞味 (消費) 期限が切れたからという理由で廃棄 したことがあると答えている ${ }^{19)}$ 。今回の調査で，家庭で の食品の保存期間をどのように判断しますかという問い に対して消費・賞味期限が過ぎると廃棄するが21. 1\%で あった。なお，調査年度が異なる2011年の今回の調査で もほぼ同じ結果であった。
保存期間を過ぎるとどの程度で廃棄するかという質問 に対しては，消費期限を過ぎると直ちにと答えた消費者 が $20.7 \% ， 4$ 日以内が $54.0 \%$ と多く，1 週間が $16.0 \%$, 腐るまでと答えた消費者が9.3\%であった。

一方，賞味期限については直ちに捨てる人の割合が $12.3 \% ， 1$ 週間，1 1 月，半年，腐るまでと回答した人 がそれぞれ $50.6 \% ， 18.8 \% ， 5.2 \% ， 11.7 \%$ あり，消 費者自身の判断にもとづいて廃棄を行っている場合が多 く, 食品の安全性を考えると, 保存期間を科学的に推定 できる情報の提供が必要である。

また，消費期限・賞味期限を過ぎても自分の判断で食 するが $66.5 \%$ ，また，消費期限・賞味期限に加えて製造 年月日を記載した場合, 製造年月日を考慮して食するか 廃棄するかを考えるが18.1\%であった。

上記の結果から，期限表示に頼らず，自らの判断で廃 棄を決める消費者が多いことが示唆された。また，賞味 期間を超過した食品への廃棄行動については，豆腐，納 豆, みそ, 八厶, しょうゆ, 乾めん類, マヨネーズ, 缶 詰, インスタントラーメン類, 植物油, 砂糖, ヨーグル トの12品目について調べた報告 ${ }^{20)}$ があるが，品目によっ て廃棄の仕方が異なる。ヨーグルト，豆腐，八厶は期限 が過ぎると「捨てる」が30\%を超えるが，その他の品目 は20\%以下である。水分の比較的多い品目は少ない品目 より期限を重要視している消費者が多いのではないかと 考えられる。また，廃棄内容をインタビューした結果に おいても，牛乳，乳製品といった水分が多く，期限の短 い食品を廃棄する消費者が比較的多かった。このような 消費者の多くは品質表示の背景を知らず自らの判断で廃 棄の期限を決めていると考えられ，安全な食品の提供と 
食品廃棄低減化のための食品品質表示

表 1 アンケートの調査表およびその結果

\begin{tabular}{|c|c|c|c|c|c|c|c|}
\hline $\begin{array}{c}\text { 質問 I 「消費期限」と「賞味期限」の } \\
\text { 違いについて }\end{array}$ & & & & & & & \\
\hline \multirow{2}{*}{$\begin{array}{l}\text { 1-1. 食品表示は1997年より, 期限表 } \\
\text { 示に変更となり,「消費期限」と「賞 } \\
\text { 味期限」が表示されることななま } \\
\text { したが,「消費期限」と「賞味期限」 } \\
\text { の違いを理解されていますか。 }\end{array}$} & $\begin{aligned} 1 & \text { : まったく } \\
& \text { 知らない }\end{aligned}$ & 2 : 知らない & $\begin{aligned} 3 & \text { : ある程度 } \\
& \text { 理解して } \\
& \text { いる }\end{aligned}$ & $\begin{aligned} 4: \text { : 理解して } \\
\text { いる }\end{aligned}$ & $\begin{aligned} 5: & : \text { よく理解 } \\
& \text { している }\end{aligned}$ & 無回答 & 合 計 \\
\hline & $7(4.7 \%)$ & $14(9.3 \%)$ & $77(51.7 \%)$ & $27(18.0 \%)$ & $25(16.7 \%)$ & $0 \quad(0.0 \%)$ & $150(100.0 \%)$ \\
\hline \multirow{2}{*}{$\begin{array}{c}\text { 1-2. マーガリン，魚肉ハムに表示さ } \\
\text { れているのは「消費期限」でしょう } \\
\text { か,「賞味期限」でしょうか。 }\end{array}$} & 1 ：消費期限 & 2 ：賞味期限 & & & & & 合 計 \\
\hline & $57(38.0 \%)$ & $89(59.3 \%)$ & - & - & - & $4(2.7 \%)$ & $150(100.0 \%)$ \\
\hline \multirow{2}{*}{$\begin{array}{l}\text { 1-3. 「賞味期限」の表示は食品の種類 } \\
\text { によって } 3 \text { 種類に分類されていまする } \\
\text { どのように分類されるかご存知です } \\
\text { か。 }\end{array}$} & $\begin{aligned} 1 & \text { : } \\
& \text { まったく } \\
& \text { 知らない }\end{aligned}$ & $2:$ 知らない & $\begin{aligned} 3: & : \text { ある程度 } \\
& \text { 理解して } \\
& \text { いる }\end{aligned}$ & $\begin{aligned} 4: \text { : 理解して } \\
\text { いる }\end{aligned}$ & $\begin{aligned} 5: & : \text { よく理解 } \\
& \text { している }\end{aligned}$ & 無回答 & 合 計 \\
\hline & $58(38.7 \%)$ & $62(41.3 \%)$ & $21(14.0 \%)$ & $4(2.7 \%)$ & $4(2.7 \%)$ & $1(0.7 \%)$ & $150(100.0 \%)$ \\
\hline \multicolumn{8}{|l|}{$\begin{array}{c}\text { 質問 II「消費期限」と「賞味期限」の } \\
\text { 設定について }\end{array}$} \\
\hline $\begin{array}{c}\text { 2-1.「消費期限」と「賞味期限」を設 } \\
\text { 定するにあたってどのような検查が } \\
\text { なされているが存知ですか。 }\end{array}$ & $61 \quad(40.7 \%)$ & $63(42.0 \%)$ & $19(12.7 \%)$ & $3 \quad(2.0 \%)$ & $3 \quad(2.0 \%)$ & $1 \quad(0.7 \%)$ & $150(100.0 \%)$ \\
\hline 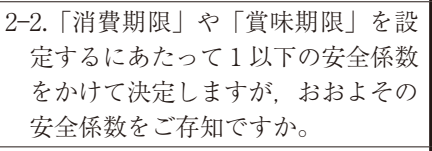 & $70(46.7 \%)$ & $70(46.7 \%)$ & $5 \quad(3.3 \%)$ & $2(1.3 \%)$ & $3 \quad(2.0 \%)$ & $0 \quad(0.0 \%)$ & $150(100.0 \%)$ \\
\hline $\begin{array}{l}\text { 2-3.「消費期限」「賞味期限」を設定は, } \\
\text { 製造業者, 小売業者, 消費者で } 3 \text { 等 } \\
\text { 分し, 設定されています。すなわち } \\
\text { 「3 分の } 1 \text { ルル」というものですが, } \\
\text { これをご存知ですか。 }\end{array}$ & $76(50.7 \%)$ & $59(39.3 \%)$ & $9(6.0 \%)$ & $2(1.3 \%)$ & $3(2.0 \%)$ & $1 \quad(0.7 \%)$ & $150(100.0 \%)$ \\
\hline \multirow[t]{2}{*}{$\begin{array}{l}\text { 2-4. 食品を購入後, 家庭で保存可能 } \\
\text { な执およう期間を推定することが } \\
\text { できますか。 }\end{array}$} & $\begin{aligned} 1 & : \text { まったく } \\
& \text { できない }\end{aligned}$ & 2：できない & $\begin{array}{c}3: \text { ある程度 } \\
\text { 可能で } \\
\text { ある }\end{array}$ & $\begin{array}{c}4 \text { : 可能で } \\
\text { ある }\end{array}$ & $\begin{aligned} 5 & : \text { よく } \\
& \text { できる }\end{aligned}$ & 無回答 & 合 計 \\
\hline & $9(6.0 \%)$ & $19(12.7 \%)$ & $98(65.3 \%)$ & $18(12.0 \%)$ & $6 \quad(4.0 \%)$ & $0 \quad(0.0 \%)$ & $150(100.0 \%)$ \\
\hline \multirow{2}{*}{$\begin{array}{c}\text { 2-5.「消費期限」が過ぎると何日ほど } \\
\text { でその食品を廃棄しますか。 }\end{array}$} & 1：直ちに & $2: 1 \sim 2$ 日 & $3: 3 \sim 4$ 日 & 4: 1 週間 & 5：腐るまで & 無回答 & 合 計 \\
\hline & $31(20.7 \%)$ & $45(30.0 \%)$ & $36(24.0 \%)$ & $24(16.0 \%)$ & $14(9.3 \%)$ & $0(0.0 \%)$ & $150(100.0 \%)$ \\
\hline \multirow{2}{*}{$\begin{array}{l}\text { 2-6.「賞味期限」が過ぎるとどの程度 } \\
\text { でその食品を廃菓しますか。 }\end{array}$} & 1：直ちに & 2: 1 週間 & $3: 1$ か月 & $4 ：$ 半年 & 5：腐るまで & 無回答 & 合 計 \\
\hline & $19(12.3 \%)$ & $78(50.6 \%)$ & $29(18.8 \%)$ & $8 \quad(5.2 \%)$ & $18(11.7 \%)$ & $2(1.3 \%)$ & $154(100.0 \%)^{* *}$ \\
\hline \multirow[t]{2}{*}{$\begin{array}{l}\text { 2-7. 食品の種類によって賞味期限は } \\
\text { 異なりますが, 食品の種類を考慮し } \\
\text { て廃棄していますか。 }\end{array}$} & $\begin{aligned} 1 & : \text { まったく } \\
& \text { 考慮 } \\
& \text { しない } \\
& \text { L }\end{aligned}$ & $\begin{array}{l}2: \text { 考慮 } \\
\text { しない }\end{array}$ & $\begin{aligned} & 3: \text { ある程度 } \\
& \text { 考慮して } \\
& \text { いる } \\
&\end{aligned}$ & $\begin{aligned} 4 & \text { : 考慮して } \\
& \text { いる }\end{aligned}$ & $\begin{aligned} 5: & \text { よく考慮 } \\
& \text { している }\end{aligned}$ & 無回答 & 合 計 \\
\hline & $9(6.0 \%)$ & $12(8.0 \%)$ & $82(54.7 \%)$ & $35(23.3 \%)$ & $10(6.7 \%)$ & $2(1.3 \%)$ & $150(100.0 \%)$ \\
\hline \multicolumn{8}{|l|}{ 質問吕＼cjkstart任意表示について } \\
\hline \multirow{2}{*}{$\begin{array}{c}\text { 3-1. 食品の期限表示には「消費期限」 } \\
\text { と「賞味期限」があります。ししい, } \\
\text { 「情報も商品のうち」と考え, 製造 } \\
\text { 年月日なと情報を表示する企業も } \\
\text { ありますが, そのような企努力を } \\
\text { どのように評価しますか。 }\end{array}$} & $\begin{array}{c}1 \text { : まったく } \\
\text { 評価 } \\
\text { (希望) } \\
\text { しない }\end{array}$ & $\begin{aligned} 2: & : \text { 評価 } \\
& \text { (希望) } \\
& \text { しない }\end{aligned}$ & $\begin{aligned} 3: & : \text { ある程度 } \\
& \text { 評価 } \\
& \text { (希望) } \\
& \text { している }\end{aligned}$ & $\begin{aligned} 4: & : \text { 評価 } \\
& \text { (希望) } \\
& \text { している }\end{aligned}$ & $\begin{aligned} 5: & \text { よく評価 } \\
& \text { (希望) } \\
& \text { している }\end{aligned}$ & 無回答 & 合 計 \\
\hline & $1(0.7 \%)$ & $15(10.0 \%)$ & $50(33.3 \%)$ & $59(39.3 \%)$ & $23(15.3 \%)$ & $2(1.3 \%)$ & $150(100.0 \%)$ \\
\hline $\begin{array}{l}\text { 3-2. 食品表示から「製造年月日」は } \\
\text { 削除されましたが, 企業の「任意表 } \\
\text { 示」として復活することを希望しま } \\
\text { すか。 }\end{array}$ & $1 \quad(0.7 \%)$ & $20(13.3 \%)$ & $56(37.3 \%)$ & $55(36.7 \%)$ & $17(11.3 \%)$ & $1(0.7 \%)$ & $150(100.0 \%)$ \\
\hline \multicolumn{8}{|l|}{$\begin{array}{l}\text { 質問 IV＼cjkstart食品廃棄行動と食品表示 } \\
\end{array}$} \\
\hline \multirow[t]{2}{*}{$\begin{array}{l}\text { 4-1. 食品購入に際して「製造年月日」 } \\
\text { 「消費期限」・賞味期限」の表示の } \\
\text { どれを重視しますか。 }\end{array}$} & $\begin{array}{l}1: \text { : 製造 } \\
\text { 年月日 }\end{array}$ & $\begin{array}{l}2 \text { : 消 費期 } \\
\text { 限 · 賞味 } \\
\text { 期限 } \\
\end{array}$ & $\begin{array}{l}3: \text { : 栄養成分 } \\
\text { 表示 }\end{array}$ & 4: 内容表示 & 5：その他 & $\begin{array}{l}\text { 無回答 } \\
\end{array}$ & 合 計 \\
\hline & $24(14.5 \%)$ & $91(54.8 \%)$ & $22(13.3 \%)$ & $23(13.9 \%)$ & $5(3.0 \%)$ & $1(0.6 \%)$ & $166(100.0 \%)^{*}$ \\
\hline \multirow[t]{2}{*}{$\begin{array}{c}\text { 4-2. 家庭での食品の保存期間をどの } \\
\text { ように判断しまか。 }\end{array}$} & $\begin{aligned} 1: & : \text { 消費 · 賞 } \\
& \text { 味期限が } \\
& \text { 過ざると } \\
& \text { 破萧する }\end{aligned}$ & $\begin{array}{r}2: \text { 消費・賞 } \\
\text { 味期限が } \\
\text { 過ぎても } \\
\text { 自分の判 } \\
\text { 断で食す } \\
\text { る } \\
\end{array}$ & $\begin{aligned} & 3: \text { : 製造年月 } \\
& \text { 日を考慮 } \\
& \text { して食す } \\
& \text { るか, 廃 } \\
& \text { 莁するか } \\
& \text { 考える } \\
&\end{aligned}$ & $\begin{aligned} 4: & \text { どちらと } \\
& \text { もいえな } \\
& \text { い }\end{aligned}$ & 5：その他 & 無回答 & 合 計 \\
\hline & $34(21.1 \%)$ & $107(66.5 \%)$ & $13(18.1 \%)$ & $4(2.5 \%)$ & $3(1.9 \%)$ & $0(0.0 \%)$ & $161(100.0 \%)^{*}$ \\
\hline
\end{tabular}

※複数回答含志 
表 2 廃棄低減化を考慮した品質表示

\begin{tabular}{|l|l|}
\hline 名 称 & \\
\hline 原材料名 & \\
\hline 内 容 量 & \\
\hline 消費・賞味期限 & \\
\hline 製 造 日 & \\
\hline 安全係数 & $\begin{array}{l}\text { 1)生物試験(大腸菌群,一般生菌数等) } \\
\text { 2)理化学試験(粘りや濁り, 比重, } \mathrm{pH} \text { 等) } \\
\text { 検査内容 }\end{array}$ \\
\hline $1 / 3$ 官能試験（外観, 味, 臭い等)
\end{tabular}

いう意味でも品質表示の設定の際の情報（検査内容, 安 全係数，1/3 ルール等）を提供することは重要である と推察された。

\section{（3）消費者意識にもとづく食品品質表示の提案}

食品小売店に並ぶ商品については，期限を定めるにあ たっては，検査が行われている。その方法や内容は食品 ごとに違うが，(1)微生物試験（大腸菌などの細菌数を調 ベる)，(2)理化学試験（粘りや濁り，比重， $\mathrm{pH}$ などを測 定), (3)官能試験（外観，味，臭い等の確認）の結果を もとに，ゆとりをみて 1 より小さい安全係数を掛け，実 際に品質が保持される期間よりも短い期間が設定されて いる ${ }^{21)}$

さらに，商品特性とは無関係に製造日から消費期限 賞味期限までの期間を，製造業者から流通業者に納入さ れるまでの期間，流通業者による販売期間，消費者が購

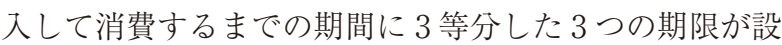
定されること（「3 分の1ルール」と呼ばれる）が多い22) したがって, 安全係数を掛け, さらに 3 分の 1 ルールを 適用すると食品の消費期限や賞味期限は大きく短縮され ることになる。今回の調査で, 安全係数の認知度は, あ る程度理解している消費者が3. 3\%，まったく知らない, 知らないを合わせると $93.4 \%$ となり，安全係数に関する 消費者の理解はきわめて低かった。また， 3 分の 1 ルー ルについては，ある程度理解している消費者は6.0\%で， まったく知らない，知らないと答えた消費者が $90.0 \%$ と 高かった。

この結果より, 品質表示の情報（検査内容，1／３ルー ル，安全係数，製造日）を知らないが，自ら食の保存期 間を算出できるとしている消費者が多いことが示された。 このようなことから安全係数や 3 分の 1 ルールの提供に より，食品廃棄の正しい判断をしやすくなるとともに廃 棄量が低減されるのではないかと推察される。したがっ てこのような内容を踏まえた表示案を表 2 に提案した。

\section{（4）品質表示の改善による消費・賞味期限切れの廃棄 量低減化の推定}

消費者の廃棄量 $P$ とし ${ }^{1)}$ ，まだ食が可能と考えられる 食品廃棄（食品ロス）の割合を $q$ とする ${ }^{1}$ 。ささらに食品 ロスのうち，賞味期限切れ等が原因での廃棄量の割合を $r$ とする ${ }^{2)}$ 。消費 · 賞味期限切れの廃棄量 $R$ とすると, $R$ は下記の式 1 によって求められる。

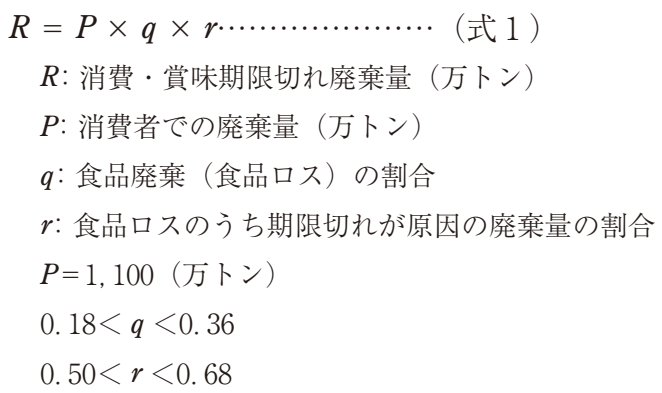

なお，既知のデー夕は， $P=1,100$ (万トン), $0.18<$ $q<0.36,0.50<r<0.68$ である。

これらの值を式 1 に挿入し, 解を求めると $100<R<$ 272万トンとなり, これらの量の低減化が可能と推定れる。 一方，食の保存期間の算出が可能と回答した人の割合 は, 性別, 年齢, 職業別では, 女性 (8.8\%), 男性が(13.4\%) で男性のほうが多かった。年齢別では，20歳代 (18.2\%), 30歳代 (17.1\%)，40～50歳代（０％)，60歳代（15.0\%） であり20歳代が多かった。職業別では，主婦 $(9.8 \%)$, 会社員 $(4.3 \%)$, 学生 $(21.1 \%)$, 自営業 $(16.7 \%)$, そ の他 (6.3\%) で, 学生が多かったため, 男性, 20歳代, 学生に食品表示の情報提供を適切に行うことは，食品廃 棄低減化のために重要であると推察された。

\section{4. まとめ}

1 ）食中毒発生件数は品質表示変更後, 家庭での食中毒 発生件数が有意に増加しており，消費期限，賞味期限 の意味が消費者に正確に理解されていなかったと推察 された。

2 ）食品輸入量に関しては, 品質表示変更後に有意に増 加しており, 品質表示変更理由の国際規格との調和に 関しては，目的を達成したと考えられる。

3 ）品質表示変更後では，廃棄エネルギーが有意に増加 した。一部の消費者団体が懸念していた品質表示変更 による食品廃棄量の増加が示された。

4 ）食品の品質表示の内容について理解不足の消費者が 多く, 設定の背景 (検査内容, 安全係数, 1 / 3 ルール) について理解している消費者はきわめて少なかった。

5 ）食の保存期間を自らの判断で決める消費者が多かっ た。科学的に安全な食の保存期間を推定するためにも 製造日, 安全係数, 3 分の 1 ルールの表示は必要である。 6 ) 安全係数を含めて表示を行うことで100～272万トン の廃棄量低減が可能と推定され, 20歳代, 男性, 学生 への情報提供が食品廃衰量低減化において効果的であ るのではないかと推察された。 


\section{文献}

1）農林水産省：平成17年度食品口又統計調査報告, 農林水産, 大臣官房統計局，農林統計協会（2007）

2 ）牛久保明邦：食品産業廃棄物と家庭系食品廃棄物の実態 とそのゆくえ，廃棄物学会誌，14（4），216-227（2003）

3 ）徳江千代子：消費期限と賞味期限, 食品表示の正しい知識 を, 2011/10/10, http://www.nodai.ac.jp/journal/research/ tokue/071202.html

4）農林水産省：食品の期限表示について，2011/10/10, http://www.maff.go.jp/j/jas/hyoji/kigen.html

5 ）消費者庁：食品の期限表示制度に関する意見交換会, 2011/10/10, http://www.caa.go.jp/foods/pdf/syokuhin427. pdf

6 ) Kelly, B., Hughes, C., Chapman, K., Chun-yu louie, J., Dixon, H., Crawford, J., King, L., Daube, M., and Slevin, T.: Consumer testing of the acceptability and effectiveness of front-of-pack food labeling systems for the Australian grocery market, Health Promotion International, 24, 120-129 (2009)

7 ) Nickerson, L.: Assessing consumers' perceptions of health claims, Food Drug Food and Drug Administration (2005) 2012/ 2 /18, http://www.fda.gov/Food/LabelingNutrition/ LabelClaims/QualifiedHealthClaims/ucm207956.htm

8 ) Kosa, K. M., Cates, S, C., Karns, S., Godwin, S.L., Chambers, D.: Consumer Knowledge and use of open dates: Results of a web-based survey, Journal of food Protection, 70 ( 5 ), 1213-1219 (2007)

9）井上幸江, 山田和彦, 池本真二, 倉田澄子, 清水俊雄, 藤澤由美子, 由田克士, 和田政裕, 坂本元子 : 栄養 - 健康 表示の社会的ニーズの解明と食育実践への活用に関する研 究, 日本栄養·食糧学会, 61（6），285-302（2008）

10）板倉ゆか子：食品表示の現状と課題, 社会運動, 373 (2011)
11）国民生活センター：食品の日付表示問題と消費者，国民 生活センター, 53-56（1995）

12）厚生労働省：年次別原因施設別食中毒発生状況, 2011/10/10 http://www.mhlw.go.jp/topics/syokuchu/

13）農林水産省：食料需給表, 2011/10/10, http://www.maff.go. $\mathrm{jp} / \mathrm{j} /$ zyukyu/fbs

14）厚生労働省：国民健康栄養調査, 2011/10/10,http://www. mhlw.go.jp/bunya/kenkou/kenkou_eiyou_chousa.html

15）総務省統計局：年齢 - 男女別人口，平成 22 年度国勢調查結 果, 2012/ 2 /12, http://www.e-stat.go.jp/SG 1 /estat/List. do?bid $=000001034991 \&$ cycode $=0$

16）総務省統計局：世帯数・世帯人員，平成 22 年度国勢調査 結 果, 2012/ 2 /12, http://www.e-stat.go.jp/SG 1 /estat/ List.do?bid $=000001034991 \&$ cycode $=0$

17）中小企業診断協会鹿児島県支部：鹿児島県の「食の安心 . 安全」に関する調査研究一消費者アンケートを中心として, 2004年度マスターセンター補助事業（2005）

18）清水みゆき, 大石卓史：食品の日付表示と食品口スの関 係性一食品ロス削減に向けた一方策一，2011年度日本フー ドシステム学会大会, 2011/6/8-9 開催

19）埼玉県総務部消費生活課：平成12年度埼玉県・市町村モ ニター合同調査 調査結果報告書, 食品の安全性及び食品 廃棄の実態について (2000)

20）高橋久仁子, 田中理恵子：加工食品に表示された賞味期 間・賞味期限に対する消費者の理解, 群馬大学教育学部紀 要 芸術·技術 ·体育·生活科学編，20，235-245（1995）

21）農林水産省：菓子業界に打ける賞味期限設定, 納入 ・販 売期限, 返品に関するアンケート調査結果, (任) 全日本菓 子協会 (2008)

22）農林水産省：食品ロスの現状とその削減に向けた対応方 向について, 食品ロスの削減に向けた検討会報告, 第 6 回, 3 (2008) 